Marquette University

e-Publications@Marquette

Theology Faculty Research and Publications

Theology, Department of

$1-1-2009$

\title{
Arboreal Metaphors and the Divine Body Traditions in the Apocalypse of Abraham
}

Andrei Orlov

Marquette University, andrei.orlov@marquette.edu

Published version. Harvard Theological Review, Vol. 102, No. 4 (2009): 439-451. DOI. (C) 2009

Cambridge University Press. Used with permission. 


\title{
Arboreal Metaphors and the Divine Body Traditions in the Apocalypse of Abraham
}

\author{
Andrei Orlov \\ Marquette University
}

The first eight chapters of the Apocalypse of Abraham, a Jewish pseudepigraphon preserved solely in its Slavonic translation, deal with the early years of the hero of the faith in the house of his father Terah. ${ }^{1}$ The main plot of this section of the

\footnotetext{
${ }^{1}$ For the published Slavonic manuscripts and fragments of Apoc. Ab., see Ioan Franko, "Книга о Аврааме праотци и патриарси" ["Тhe Book about the Forefather and the Patriarch Abraham"], in Aпокріфи і легенди з украінських рукописів [The Apocrypha and the Legends From the Ukrainian Manuscripts] (5 vols.; Monumenta Linguae Necnon Litterarum Ukraino-Russicarum [Ruthenicarum]; Lvov, Ukraine, 1896-1910) 1:80-86; Alexander I. Jacimirskij, “Откровение Авраама" ["The Apocalypse of Abraham"], in Апокрифы ветхозаветные [The Old Testament Pseudepigrapha] (vol. 1 of Библиографический обзор апокрифов в южнославянской и русской письменности [The Bibliographical Survey of Apocryphal Writings in South Slavonic and Old Russian Literature]; Petrograd: The Russian Imperial Academy of Sciences, 1921) 99-100; Petr P. Novickij, ed., "Откровение Авраама" ["The Apocalypse of Abraham"], in Общество любителей древней письменности [The Society of Lovers of Ancient Literature] 99.2 (St. Petersburg: Markov, 1891); Ivan Ja. Porfir'ev, "Откровение Авраама" ["The Apocalypse of Abraham"], in Апокрифические сказания о ветхозаветных лицах и событиях по рукописям соловецкой библиотеки [Тһе Apocryphal Stories about Old Testament Characters and Events according to the Manuscripts of the Solovetzkoj Library] (Sbornik Otdelenija russkogo jazyka i slovesnosti Imperatorskoj akademii nauk 17.1; St. Petersburg: The Russian Imperial Academy of Sciences, 1877) 111-30; Belkis PhilonenkoSayar and Marc Philonenko, L'Apocalypse d'Abraham. Introduction, texte slave, traduction et notes (Semitica 31; Paris, 1981) 36-105; Alexander N. Pypin, Ложные и отреченные книги славянской и русской старины. Памятники старинной русской литературы, издаваемые графом Григорием Кушелевым-Безбородко [The False and Rejected Books of Slavonic and Russian Antiquity: Memorials of Ancient Russian Literature] (ed. Count Gregory KushelevBezborodko; St. Petersburg: Kulesh, 1860-62) 3:24-36; Ryszard Rubinkiewicz, L'Apocalypse d'Abraham en vieux slave. Édition critique du texte, introduction, traduction et commentaire (Towarzystwo Naukowe Katolickiego Uniwersytetu Lubelskiego: Źródła i monografie 129; Lublin, 1987) 98-256; Izmail I. Sreznevskij, “Книги Откровения Авраама” [The Apocalypse of Abraham],
}

HTR 102:4 (2009) 439-51 
text revolves around the family business of manufacturing idols. Terah and his sons are portrayed as craftsmen carving religious figures out of wood, stone, gold, silver, brass, and iron. The zeal with which the family pursues its idolatrous craft suggests that the text does not view the household of Terah as just another family workshop producing religious artifacts for sale. Although the sacerdotal status of Abraham's family remains clouded in rather obscure imagery, the authors of the Slavonic apocalypse seem to envision the members of Terah's household as cultic servants whose "house" serves as a metaphor for the sanctuary polluted by idolatrous worship. From the very first lines of the apocalypse the reader learns that Abraham and Terah are involved in sacrificial rituals in temples. ${ }^{2}$ The aggadic section of the text, which narrates Terah's and Abraham's interactions with the "statues," culminates in the destruction of the "house" along with its idols in a fire sent by God. It is possible that the Apocalypse of Abraham, which was written in the first centuries of the Common Era, ${ }^{3}$ when Jewish communities were facing a wide array of challenges including the loss of the Temple, is drawing here on familiar metaphors derived from the Book of Ezekiel, which construes idolatry as the main reason for the destruction of the terrestrial sanctuary. Like Ezekiel, the

in Известия Императорской академии наук по отделению русского языка и словесности [Proceedings of the Imperial Academy of Sciences, Division of Russian Language and Literature] (St. Petersburg: Russian Academy of Sciences, 1861-1863) 10:648-65; Nikolaj S. Tihonravov, Памятники отреченной русской литературы [Memorials of Russian Apocryphal Literature] (2 vols.; St. Petersburg: Obschestvennaja Pol'za, 1863) 1:32-77. For translations of the Apoc. Ab., see Nathanael Bonwetsch, Die Apokalypse Abrahams. Das Testament der vierzig Märtyrer (Studien zur Geschichte der Theologie und der Kirche Bd. 1, Heft 1; Leipzig: Deichert, 1897); George Herbert Box and J. I. Landsman, Apocalypse of Abraham (TED 1.10; London: Macmillan, 1918) 35-87; Mario Enrietti and Paolo Sacchi, "Apocalisse di Abramo," in Apocrifi dell'Antico Testamento (ed. Paolo Sacchi et al.; 5 vols.; Turin: Unione tipografico-editrice torinese, 1981-1997) 3:61-110; Alexander Kulik, Retroverting Slavonic Pseudepigrapha: Toward the Original of the Apocalypse of Abraham (Atlanta: SBL, 2004) 9-35; A. Pennington, "Apocalypse of Abraham," AOT 363-491; Donka Petkanova, "Откровение на Авраам" [“The Apocalypse of Abraham”], in Старобългарска Eсхатология. Антология [Old Bulgarian Eschatology: Anthology] (ed. Donka Petkanova and Anisava Miltenova; Slavia Orthodoxa; Sofia: Slavica, 1993) 17-30; Belkis Philonenko-Sayar and Marc Philonenko, "Die Apokalypse Abrahams," JSHRZ 5.5 (Gütersloh: Mohn, 1982) 413-60; Paul Rießler, "Apokalypse des Abraham," in Altjüdisches Schriftum außerhalb der Bibel (Freiberg: Kerle, 1928) 13-39, 1267-69; Ryszard Rubinkiewicz, "Apocalypse of Abraham,” OTP 1:681-705; idem, "Apocalypsa Abrahama," in Apokryfy Starego Testamentu (ed. R. Rubinkiewicz; Warsaw: Oficyna Wydawnicza "Vocatio," 1999) 460-81.

${ }^{2}$ Apocalypse of Abraham 1:2-3: “. . . at the time when my lot came up, when I had finished the services of my father Terah's sacrifice to his gods of wood, stone, gold, silver, brass and iron, I, Abraham, having entered their temple for the service ..." (Kulik, Retroverting the Slavonic Pseudepigrapha, 9).

${ }^{3}$ On the date and provenance of Apoc. Ab., see Box and Landsman, The Apocalypse of Abraham, xv-xix; Philonenko-Sayar and Philonenko, L'Apocalypse d'Abraham, 34-35; Rubinkiewicz, "Apocalypse of Abraham," 683; idem, L'Apocalypse d'Abraham en vieux slave, 70-73; Alexander Kulik, "К датировке 'Откровения Авраама" " ["About the Date of the Apocalypse of Abraham"], In Memoriam of Ja. S. Lur'e (eds. N. M. Botvinnik and Je. I. Vaneeva; St. Petersburg, 1997) 189-95; idem, Retroverting the Slavonic Pseudepigrapha, 2-3. 
hero of the Slavonic apocalypse is allowed to behold the true place of worship, the heavenly shrine associated with the divine throne. Yet despite the fact that the Book of Ezekiel plays a significant role in shaping the Abrahamic pseudepigraphon, ${ }^{4}$ there is a curious difference between the two visionary accounts. While in Ezekiel the false idols of the perished temple are contrasted with the true form of the deity enthroned on the divine chariot, the Apocalypse of Abraham denies its hero a vision of the anthropomorphic Glory of God. When in the second part of the apocalypse Abraham travels to the upper heaven to behold the throne of God, evoking the classic Ezekielian description, he does not see any divine form on the chariot. Scholars have noted that while they preserve some features of Ezekiel's angelology, the authors of the Slavonic apocalypse appear to be carefully avoiding the anthropomorphic description of the divine Kavod, substituting references to the divine Voice. ${ }^{5}$ The common interpretation is that the Apocalypse of Abraham deliberately seeks "to exclude all reference to the human figure mentioned in Ezekiel 1."6

In view of this polemical stance against the anthropomorphic understanding of God in the second part of the Apocalypse of Abraham, it is possible that the first part of the pseudepigraphon, which is imbued with imagery of idolatrous figures, might also contain a polemic against the divine body traditions. ${ }^{7}$ This article will explore the possible anti-anthropomorphic tendencies in the first part of the Slavonic apocalypse.

${ }^{4}$ Scholars have noted that the seer's vision of the divine throne found in the Apocalypse of Abraham "draws heavily on Ezekiel and stands directly in the tradition of Merkabah speculation." John Collins, The Apocalyptic Imagination: An Introduction to Jewish Apocalyptic Literature (2d ed.; Grand Rapids, Mich.: Eerdmans, 1998) 183. See also Ithmar Gruenwald, Apocalyptic and Merkavah Mysticism (AGAJU 14; Leiden: Brill, 1980) 55-57; Christopher Rowland, The Open Heaven: A Study of Apocalyptic in Judaism and Early Christianity (New York: Crossroad, 1982) 86-87.

${ }^{5}$ Such polemical development, which attempts to confront the anthropomorphic understanding of the Deity by replacing it with the imagery of the divine Voice or Name, has its roots in the Bible, particularly in the Book of Deuteronomy and later deuteronomistic writings. On these traditions, see Oskar Grether, Name und Wort Gottes im Alten Testament (BZAW 64; Giessen: Toepelmann, 1934) 1-58; Moshe Weinfeld, Deuteronomy and the Deuteronomic School (Oxford: Clarendon, 1972) 191-201; Tryggve N. D. Mettinger, The Dethronement of Sabaoth: Studies in the Shem and Kabod Theologies (Coniectanea Biblica. Old Testament Series 18; Lund: Wallin \& Dalholm, 1982) 124-29; Ian Wilson, Out of the Midst of Fire: Divine Presence in Deuteronomy (SBLDS 151; Atlanta: Scholars Press, 1995) 1-15; Charles A. Gieschen, Angelomorphic Christology: Antecedents and Early Evidence (AGAJU 42; Leiden: Brill, 1998) 51-123. On the formative role of the Deuteronomic tradition for the theophanic imagery of the Apocalypse of Abraham, see Andrei Orlov, "Praxis of the Voice: The Divine Name Traditions in the Apocalypse of Abraham," JBL 127 (2008) 53-70, at 58-60.

${ }^{6}$ Rowland, The Open Heaven, 87.

${ }^{7}$ For a discussion of the divine body traditions in biblical, pseudepigraphic, and rabbinic materials see Andrei Orlov, The Enoch-Metatron Tradition (TSAJ 107; Tübingen: Mohr/Siebeck, 2005) 143-46, 211-52; idem, " 'Without Measure and Without Analogy': The Tradition of the Divine Body in 2 (Slavonic) Enoch," in From Apocalypticism to Merkabah Mysticism: Studies in the Slavonic Pseudepigrapha (ed. Andrei Orlov; JSJSupp. 114; Leiden: Brill, 2007) 149-74. 


\section{Bar-Eshath, the Wooden Idol}

The introductory chapters of the Apocalypse of Abraham entertain the reader with elaborate mocking portrayals of the idols produced in the household of Terah. Often, the main purpose of these narrations is to demonstrate the limited supernatural prowess of the anthropomorphic figures, whose spiritual impotence is then contrasted with the power of the incorporeal God. It is possible that in these mocking accounts of the idols found in the first eight chapters of the Apocalypse of Abraham the reader encounters one of the more vivid testimonies to the work's overall retraction of the anthropomorphic understanding of the Deity. Possibly mindful of the broader extra-biblical context of Abraham's biblical biography and his role as a fighter against the idolatrous practices of his father Terah, the work's authors seem to be using the patriarch's story to advance their own anticorporeal agenda. ${ }^{8}$

The limited scope of this investigation does not allow us to explore all depictions of the idolatrous figures found in the first part of the pseudepigraphon. This study will investigate only one polemical portrayal: the account involving the wooden idol Bar-Eshath (Slav. Варисать). ${ }^{9}$ This mysterious idol first appears in chapter five, where Abraham is sent by his father to gather wooden chips left from manufacturing idols in order to make fire and prepare a meal. In the pile of wooden splinters Abraham finds a small figurine whose forehead is decorated with the name Bar-Eshath. ${ }^{10}$ Skeptical of idols, Abraham decides to challenge their supernatural power by placing Bar-Eshath near fire and, with irony, ordering him to confine the flames. ${ }^{11}$ The challenge leads to disastrous consequences for the wooden figurine, whom Abraham observes turn into a pile of dust after being enveloped and toppled over by fire.

The story of the fiery challenge of the wooden idol appears to fit nicely into the overall anti-anthropomorphic argument of the text. It polemically evokes two pivotal biblical theophanic accounts associated with the divine body ideology - Ezekiel 1 and Daniel 3 - that contain depictions of divine beings in the midst of fire. Although the purpose of these two biblical accounts is to highlight the distinction between true and false representations of the Deity by depicting the authentic form enduring fire, in the Slavonic apocalypse the argument takes a different turn. Here, it is not a fiery divine form but its incorporeal manifestation - the divine Voice appearing in the midst of fire ${ }^{12}$ - that is contrasted with the anthropomorphic idolatrous

${ }^{8}$ For the background of the story of Abraham as a fighter with idols in the Book of Jubilees and later rabbinic materials (Gen. Rab. 38:13, Tanna debe Eliahu 2:25, S. Eli. Rab. 33), see Box and Landsman, The Apocalypse of Abraham, 88-94; Rubinkiewicz, L'Apocalypse d'Abraham, 43-49.

${ }^{9}$ On Bar-Eshath and the background of this name, see Kulik, Retroverting the Slavonic Pseudepigrapha, 63.

${ }^{10}$ Ibid., 12.

${ }^{11}$ Ibid., 12-13.

${ }^{12}$ On hypostatic voice of God, see James H. Charlesworth, "The Jewish Roots of Christology: The Discovery of the Hypostatic Voice," SJT 39 (1986) 19-41. 
figure that perishes in the flames. I have previously explored this aspect of BarEshath's narrative, arguing that it represents a polemical variation on the divine body traditions. ${ }^{13}$ In this study I will continue to probe polemical features of the Bar-Eshath account by focusing on the symbolic dimension of the story in chapter six of the Slavonic apocalypse. There, the story of the "fall" of the wooden idol is poetically retold, this time in mythological language reminiscent of Ezekiel and Daniel, two biblical writings in which the ideology of the divine body reaches its most emphatic, developed articulation.

\section{The Biblical Background of the Tale of the Fallen Tree}

The Apocalypse of Abraham 6:10-17 offers the following poetic tale about the origin and the final destiny of the wooden statue, conveyed through primordial mythological imagery:

But Bar-Eshath, <your god, before he was made had been rooted in the ground. Being great and wondrous (великъ сы и дивен), with branches, flowers, and [various] beauties (похвалами). And you cut him with an ax, and by your skill the god was made. And behold, he has dried up, and his sap (myкота его) is gone. He fell from the heights to the ground, and he went from greatness to insignificance, and his appearance has faded.> [Now] he himself has been burned up by the fire, and he turned into ashes and is not more. ${ }^{14}$

This description of the wondrous tree found in the Slavonic apocalypse appears to draw on the arboreal metaphors in Ezekiel 31 and Daniel 4. It is no accident that the authors of the Slavonic apocalypse bring these two theophanic accounts into play. ${ }^{15}$ Several studies have observed that these two biblical texts, permeated with corporeal ideology, exercise a formative influence on the theophanic and angelological imagery found in various parts of the Apocalypse of Abraham. To better understand their appropriation in the Slavonic account, we must explore the ideological background of the arboreal portrayals in Ezekiel and Daniel.

As noted above, the Apocalypse of Abraham draws on a cluster of motifs from the Book of Ezekiel, while at the same time reshaping them by eliminating their anthropomorphic details. ${ }^{16}$ The authors' peculiar use of the Ezekielian chariot

\footnotetext{
${ }^{13}$ See Andrei Orlov, “"The Gods of My Father Terah’: Abraham the Iconoclast and the Polemics with the Divine Body Traditions in the Apocalypse of Abraham," JSP 18 (2008) 33-53.

${ }^{14}$ Philonenko-Sayar and Philonenko, L'Apocalypse d'Abraham, 48; Kulik, Retroverting Slavonic Pseudepigrapha, 14. In Alexander Kulik's English translation of the Apocalypse of Abraham the elements of the text which do not occur in the version of the Sylvester Codex (MS S) are enclosed.

${ }^{15}$ Kulik (Retroverting the Slavonic Pseudepigrapha, 72) also points out the text's similarity to Isa 44:14-20.

${ }^{16}$ On the author's use of the Ezekielian traditions, see Rubinkiewicz, "Apocalypse of Abraham," 1.685. In his monograph, L'Apocalypse d'Abraham en vieux slave, Rubinkiewicz provides a helpful outline of the usage of Ezekielian traditions in Apoc. Ab. He notes that "among the prophetic books, the book of Ezekiel plays for our author the same role as Genesis in the Pentateuch. The vision of the divine throne (Apoc. Ab. 18) is inspired by Ezekiel 1 and 10. Abraham sees the four living
} 
imagery in Abraham's vision of the upper heaven has been investigated in detail in previous studies. ${ }^{17}$ Although the anthropomorphic thrust of Ezekiel understandably comes to the fore in the account of the vision of the divine chariot where the seer beholds the human-like Kavod, other parts of the book also contain implicit or explicit affirmations of the corporeal ideology of the priestly tradition. It is noteworthy for our investigation that the corporeal ideology of both Ezekiel and the Priestly source is shaped by the tenets of the Adamic tradition and its technical terminology. ${ }^{18}$ One example of this corporeal development involving Adamic imagery may be found in Ezekiel 31, which features a portrayal of a wondrous tree that first flourishes in the Garden of God and is then doomed by the Deity and destroyed by foreigners.

Like any profound religious symbol, this arboreal metaphor can be understood in a number of ways. The passage has often been interpreted as a reference to the destruction of nations or their arrogant rulers. There is, however, another interpretation that recalls the story of Adam. The peculiar reference to the location of the wondrous tree in the Garden of Eden (עדן) and its expulsion from this distinguished topos exhibits parallels to the story of the Protoplast, who once also enjoyed an exalted status in the Garden but was then expelled by the Deity from his heavenly abode. Like the mysterious trees in the Ezekielian and Danielic accounts, the protoplast, too, was once of enormous stature. Several passages in Philo and some pseudepigraphical accounts, including the tradition that appears in Apoc. Ab. 23:4-6, describe Adam's body as great in height, terrible in breadth, and incomparable in aspect. ${ }^{19}$ Moreover some Jewish traditions hint to the radiant nature

creatures (Apoc. Ab. 18:5-11) depicted in Ezek 1 and 10. He also sees the wheels of fire decorated with eyes all around (Apoc. Ab. 18:3), the throne (Apoc. Ab. 18:3; Ezek 1:26), the chariot (Apoc. $A b .18: 12$ and Ezek 10:6); he hears the voice of God (Apoc. Ab. 19:1 and Ezek 1:28). When the cloud of fire raises up, he can hear 'the voice like the roaring sea' (Apoc. Ab. 18:1; Ezek 1:24). There is no doubt that the author of the Apocalypse of Abraham takes the texts of Ezekiel 1 and 10 as sources of inspiration."

${ }^{17}$ Christopher Rowland, "The Vision of God in Apocalyptic Literature," JSJ 10 (1979) 137-54; idem, The Open Heaven, 86-87; Orlov, "Praxis of the Voice," 53-70; idem, "The Pteromorphic Angelology of the Apocalypse of Abraham," CBQ 71 (2009) 830-42.

${ }^{18}$ In recent years scholars have become increasingly aware of the formative value of the Adamic traditions in the shaping of ideologies about the anthropomorphic body of the Deity. Already in the Book of Ezekiel the imagery of the human-like Kavod is connected to the protological developments reflected in the Genesis account where humanity is said to be created in the image of God.

${ }^{19}$ Several early Jewish sources attest to the lore about the enormous body that Adam possessed before his transgression in Eden. Thus, Philo in $Q G 1.32$ mentions a tradition according to which the first humans received at their creation bodies of vast size reaching a gigantic height: ". . . [the first humans] . . . were provided with a very great body and the magnitude of a giant. . .." (Philo, Questions and Answers on Genesis [trans. R. Marcus; Cambridge, Mass.: Harvard University Press, 1949] 19). Moreover, in some pseudepigraphic accounts Adam's body is portrayed, not simply as gigantic, but even as comparable to the dimensions of the divine body. Thus, in several pseudepigraphic materials the depictions of Adam's stature are linked to the imagery of the enthroned divine anthropomorphic manifestation known from the Priestly and Ezekielian sources as God's Kavod. 
of Adam's gigantic body. This great body is also said to be luminous and clothed with what is often described in Jewish traditions as the "garment of glory." 20

Yet according to the Adamic traditions, the condition of the protoplast's body changed dramatically after the fall, when he lost his great beauty, stature, and luminosity. In view of these parallels to the Adamic developments, it has been proposed that Ezekiel 31 and Daniel 4 may be symbolic renditions of the story of the first human, where the metaphor of the fallen tree forewarns the demise of the original condition of humanity. ${ }^{21}$

The use of the Adam story as a metaphor for the fall of the exalted "divine humanity" is of paramount significance in the conceptual framework of the corporeal ideologies found in the Book of Ezekiel and the Book of Daniel. Previous studies have noted that the divine body traditions often juxtapose dialectically the exaltation and demotion of the mediatorial figures to the end of both promoting and delimiting the divinization of humanity. ${ }^{22}$ The demise of the wondrous trees thus appears to fit well into this dialectical interplay of reaffirmations and deconstructions of various corporeal ideologies. ${ }^{23}$

${ }^{20}$ The pseudepigraphic and rabbinic sources also refer to the luminosity of the original human's body, which, like the divine body, emitted light. Thus, the Targums attest to the prelapsarian luminosity of Adam and Eve in the Garden of Eden. The biblical background for these traditions includes Gen 3:21, in which "the Lord God made for Adam and his wife garments of skin and clothed them." The Targumic traditions, both Palestinian and Babylonian, read "garments of glory" instead of "garments of skin." For example, in Targum Pseudo-Jonathan on Gen 3:21 the following tradition can be found: "And the Lord God made garments of glory for Adam and for his wife from the skin which the serpent had cast off (to be worn) on the skin of their (garments of) fingernails of which they had been stripped, and he clothed them" (Targum Pseudo-Jonathan: Genesis [trans. Michael Maher, M.S.C.; The Aramaic Bible, 1B; Collegeville, 1992] 29). Targum Neofiti on Gen 3:21 unveils a similar tradition: "And the Lord God made for Adam and for his wife garments of glory, for the skin of their flesh, and he clothed them" (Targum Neofiti 1: Genesis [trans. Martin McNamara, M.S.C.; The Aramaic Bible 1A; Collegeville, Minn., 1992] 62-63; Alejandro Díez Macho, Neophiti 1: Targum Palestinense MS de la Biblioteca Vaticana [Madrid: Consejo Superior de Investigaciones Científicas, 1968] 1.19). The Fragmentary Targum on Gen 3:21 also uses the imagery of glorious garments: "And He made: And the memra of the Lord God created for Adam and his wife precious garments [for] the skin of their flesh, and He clothed them" (Michael I. Klein, The Fragment-Targums of the Pentateuch according to Their Extant Sources [2 vols.; AB 76; Rome, 1980] 1.46, 2.7). Targum Onqelos on Gen 3:21 reads: "And the Lord God made for Adam and his wife garments of honor for the skin of their flesh, and He clothed them" (Targum Onqelos to Genesis [trans. Bernard Grossfeld; The Aramaic Bible 6; Wilmington, Del.: Glazier, 1988] 46; The Bible in Aramaic Based on Old Manuscripts and Printed Texts [ed. Alexander Sperber; Leiden: Brill, 1959] 1.5).

${ }^{21}$ See, for example, Chrispin Fletcher-Louis, All the Glory of Adam: Liturgical Anthropology in the Dead Sea Scrolls (STDJ 42; Leiden: Brill, 2002) 101-3; Silviu N. Bunta, "The Mēsu-Tree and the Animal Inside: Theomorphism and Theriomorphism in Daniel 4," in The Theophaneia School: Jewish Roots of Eastern Christian Mysticism (ed. Basil Lourié and Andrei Orlov; Scrinium 3; St. Petersburg: Byzantinorossica, 2007) 364-84.

${ }^{22}$ Daphna Arbel, “ 'Seal of Resemblance, Full of Wisdom, and Perfect in Beauty': The Enoch/ Metatron Narrative of 3 Enoch and Ezekiel 28," HTR 98 (2005) 121-42.

${ }^{23}$ Another example of such dialectical interplay of reaffirmation and demotion can be found in Ezek 28:1-19, a symbolic depiction of judgment against the prince of Tyre. This account also 
These conceptual developments involving the symbolism of the wondrous trees in Ezekiel 31 and Daniel 4 bring us back to the arboreal imagery in Apoc. Ab. 6:1011. In this passage, the authors seem to evoke cautiously the aforementioned biblical accounts when Bar-Eshath is compared to the wondrous tree. All three accounts emphasize the beauty of the protological tree, and in all three stories the tree faces eventual demise, which is depicted as a fall from heights to the ground. ${ }^{24}$

In highlighting the similarities between the biblical and pseudepigraphic accounts of the great tree, it is also important to note the distinct purposes that arboreal imagery serves in Ezekiel and Daniel on one hand and the Apocalypse of Abraham on the other. While the imagery of the fallen tree in Ezekiel and Daniel is employed to advance the ideology of divine corporeality, in the Slavonic apocalypse it is unambiguously set against traditions of divine corporeality. One peculiar detail illuminates this ideological difference. While in the biblical stories the symbolic arboreal stature of exalted humanity is diminished by the will of the Creator ${ }^{25}$ and

appears to be informed by the Adamic traditions. As will be shown later, Ezek 28 also contributes to the background for the imagery found in the Apoc. Ab. since in both texts the idolatrous statues are destroyed by fire.

${ }^{24}$ The concept of the cosmic tree as the building material for the divine figure found in the arboreal hymn of Apoc. Ab. appears to be reminiscent not only of the descriptions in Ezek 31 and Dan 4 but also some Mesopotamian traditions about the cosmic tree also known as the Mēsu-Tree. Scholars have noted that the tradition about the wondrous tree reflected in Ezek 31 seems to draw on Mesopotamian traditions about the Mēsu-Tree, a cosmic plant envisioned as the building material for the divine statues. The traditions about the mythological tree are documented in several sources, including the Book of Erra, a Mesopotamian work dated between the eleventh and eighth centuries B.C.E. The Book of Erra 1:150-56 reads:

"Where is the mēsu tree, the flesh of the gods, the ornament of the king of the uni[verse]?

That pure tree, that august youngster suited to supremacy,

Whose roots reached as deep down as the bottom of the underwor[ld]: a hundred double hours through the vast sea waters;

Whose top reached as high as the sky of [Anum]?

Where is the glittering zaginduru stone...

Where is Ninildu, the great woodcarver of my godhead,

Who carries the golden axe, who knows his own. ..." (L. Cagni, The Poem of Erra [SANE 1/3; Malibu: Undena, 1977] 32).

This passage vividly demonstrates that the Mesopotamian "matrix" of traditions about the gigantic cosmic tree as the building material for the divine statues is reflected not only in Ezekiel, but also in the Slavonic apocalypse, where the "flesh" of the cosmic tree serves as the building material for the idolatrous statue of Bar-Eshath. Strikingly, the accounts of the cosmic tree in Apoc. Ab. and the passage in the Book of Erra share several features, including the motif of a craftsman carving the wooden statues of a godhead with his axe. On the Mesopotamian traditions about the Mēsu-Tree and their connection to Ezek 31 and Dan 4, see Bunta, "The Mēsu-Tree and the Animal Inside."

${ }^{25}$ The motif of the Deity demoting or diminishing the original gigantic stature of the first human is a dialectical device of reaffirmation widespread in the pseudepigraphic and rabbinic materials associated with the divine body traditions. See Jarl Fossum, "The Adorable Adam of the Mystics and 
both of the biblical trees are cut by celestial beings - in Ezekiel by God and in Daniel by the heavenly envoy - in the Apocalypse of Abraham the tree is cut down not by the Deity but by Abraham's idolatrous father Terah, who throughout the narrative is portrayed as a "creator" of his idols in a manner ironically reminiscent of God's role in the biblical account of creation. ${ }^{26}$ In Apoc. Ab. 4:3, Abraham tells Terah that he is a god to his idols since he made them. Here again, as in the accounts in Ezekiel and Daniel, the subtle presence of Adamic motifs can be discerned. Yet, unlike the prophetic books in which the Adamic currents reaffirm the possibility of a human-like body of the Deity who fashions his beloved creature in his own image, in the Slavonic apocalypse these currents run against such a possibility.

\section{The Demoted Cherub}

The arboreal hymn of the demise of Bar-Eshath in Apoc. Ab. 6:10-17, which defines him as a god, brings us to another important passage: Ezek 28:1-19. This latter passage contains two oracles about an enigmatic celestial figure, an anointed cherub (כרוב ממשח) whom the text identifies as the prince of Tyre and who, like Bar-Eshath, appears to be envisioned as a demoted idol.

It is noteworthy that, like the wooden idol, the main character of this Ezekielian passage is also repeatedly described in ironic fashion as a god. Further, it is intriguing that both the hymn in the Slavonic apocalypse and the account in Ezekiel 28 describe the "idols" as wondrous creatures decorated with "beauties." Although the Slavonic text does not elaborate on the nature of Bar-Eshath's "beauties" (Slav. похваль) $){ }^{27}$ the passage in Ezekiel describes the cherub as "the model of perfection" (חותם תכנית), "perfect in beauty" (כליל יפי), and decorated with precious stones. It appears that in both accounts references to the characters" "beauties" indicate their exalted status. ${ }^{28}$ Scholars have observed that the attribution of "beauties" to the cherub evokes another important "representation" of the Deity: the supreme angel Metatron, who according to the Sefer Hekhalot was also "enhanced" with various "beauties" in the form of precious stones. ${ }^{29}$ In this context the reference to the protagonist of the Merkabah tradition does not seem out of place, given that he himself might also be viewed as a conceptual nexus reflecting the dynamics of both the exaltation and the demotion of humanity. In this capacity he can be envisioned as a sort of "idol" who serves as a stumbling block for the infamous visionary of

the Rebuttals of the Rabbis," in Geschichte-Tradition-Reflexion. Festschrift für Martin Hengel zum 70. Geburtstag (ed. Hubert Cancik, Hermann Lichtenberger, and Peter Schäfer; 3 vols.; Tübingen: Mohr, 1996) 1:529-30.

${ }^{26}$ Thus, for example, Apoc. Ab. 6.2 relates Terah's "creation" of the bodies of the idols.

${ }^{27}$ This Slavonic word can be literally translated as "praises." For a discussion of the translation of Slavonic “похвала" as "beauty," see Kulik, Retroverting the Slavonic Pseudepigrapha, 73 n. 6.

${ }^{28}$ Thus, Daphna Arbel observes that "the bejeweled garb covered with precious stones that adorns the primal figure further highlights his state of exaltation." Arbel, “'Seal of Resemblance, Full of Wisdom, and Perfect in Beauty,", 131.

${ }^{29} \mathrm{Ibid}$. 
the Talmud, Elisha b. Abuyah, who, according to b. Hag. 15a, takes Metatron to be the second deity in heaven, leading him to the heretical conclusion that there are two heavenly "powers." The passage in Hagigah next depicts the demotion of the dangerous "idol." The supreme angel is publicly punished in front of celestial hosts with sixty fiery lashes in order to prevent future confusion between the Deity and his angelic replica.

Returning to the similarities between the stories of the anointed cherub and BarEshath, it should be noted that both seem to contain traces of corporeal ideologies in their symbolic rendering of the story of Adam's exaltation and fall. ${ }^{30}$ Thus in Ezekiel the cherub, like Bar-Eshath, falls from "the heights to the ground," being cast out as a profane thing from the mountain of God.

It is noteworthy that both texts, like the Adamic traditions, appear to envision the process of demotion as the loss of the original condition of the characters. Ezekiel 28 hints that the cherub was originally installed like the divine Kavod on the holy mountain in the midst of the fire: "You were on the holy mountain of God; in the midst of the stones of fire (אבני אש) you walked." The story continues with the exalted figure being expelled from the exalted topos by its guardians: "I cast you as a profane thing from the mountain of God (מהר אלהים), and the guardian cherub drove you out from the midst of the stones of fire." According to the text, when the cherub was expelled from his original lofty abode he was "cast to the ground" and "exposed" before spectators. In light of the possible Adamic background of the Ezekielian oracles, demotion to the lower realm and exposure to the gazing public can be understood as references to the protoplast's loss of his original luminous garment after the fall. A similar tradition about the loss of the first human's shining attire seems to be present in the Slavonic apocalypse, which describes the "fall" of Bar-Eshath as the "fading" of his primordial condition. Apocalypse of Abraham 6:14-15 reads: "He fell from the heights to the ground, and he went from greatness to insignificance, and his appearance has faded. ..."31

It is also intriguing that in both stories the characters share the same final destiny: their "bodies" turn into ashes by fire. As others have noted, in Ezekiel the demoted

${ }^{30}$ On the Adamic background of Ezek 28 see James Barr, “'Thou art the Cherub': Ezek 28.14 and the Postexilic Understanding of Genesis 2-3," in Priests, Prophets and Scribes: Essays on the Formation and Heritage of Second Temple Judaism in Honour of Joseph Blenkinsopp (ed. Eugene Ulrich et al.; JSOTSupp. 149; Sheffield, England: JSOT Press, 1992) 213-23; Norman C. Habel, "Ezekiel 28 and the Fall of the First Man," Concordia Theological Monthly 38 (1967) 516-24; Knud Jeppesen, "You are a Cherub, but no God!" SJOT 1 (1991) 83-94; Dale Launderville, O.S.B., "Ezekiel's Cherub: A Promising Symbol or a Dangerous Idol?" CBQ 65 (2004) 165-83; Oswald Loretz, "Der Sturz des Fürsten von Tyrus (Ezek 28:1-19)," UF 8 (1976) 455-58; Herbert G. May, "The King in the Garden of Eden: A Study of Ezekiel 28:12-19," in Israel's Prophetic Heritage: Essays in Honor of James Muilenburg (eds. Bernhard Anderson and Walter Harrelson; New York: Harper, 1962) 166-76; James E. Miller, "The Maelaek of Tyre (Ezekiel 28: 11-19)," ZAW 105 (1994) 497-501; Anthony J. Williams, “The Mythological Background of Ezekiel 28:12-19?” BTB 6 (1976) 49-61; Kalman Yaron, "The Dirge over the King of Tyre," ASTI 3 (1964) 28-57.

${ }^{31}$ Kulik, Retroverting the Slavonic Pseudepigrapha, 14. 
cherub is clearly envisioned as an idolatrous statue destroyed by fire. It has further been noted that the "cremation of the king of Tyre resembles the burning of a statue and the scattering of its ashes on the ground or in the underworld. If the king of Tyre is identified as a cherub, represented as a statue, and punished for claiming to be a god, then the burning of this statue can be seen as the rite of disposal of the impurity of idolatry." 32

The divine body traditions, and especially their peculiar use of the fire test in the adjudication between true and false representations of the Deity, appear to be present in both the Apocalypse of Abraham and the Ezekielian oracles, since the anointed cherub is first depicted as passing the fiery test ("in the midst of the stones of fire you walked") and then failing it ("I brought forth fire from the midst of you; it consumed you, and I turned you to ashes").

\section{The Divine Face}

There is no doubt that the symbolism of various Adamic currents permeates the story of Bar-Eshath. In this respect it is especially interesting to examine the aforementioned passage from Apocalypse of Abraham 6, where some peculiar details accompany the fall of the wooden idol. The text relates that Bar-Eshath fell from the heights to the ground and that his condition was changed from greatness to smallness (оть веліиства пріиде в малость). ${ }^{33}$ Although in the course of narration the wooden statue literally falls to the ground, it appears that the reference to the idol's fall has an additional symbolic dimension, reminiscent of the story of the protoplast. The "Adamic" aspect of the terminology in Apoc. Ab. 6:15 can be further clarified by comparing the vocabulary of this passage to the terminology found in another central pseudepigraphical account that survived in the Slavonic language, 2 (Slavonic) Apocalypse of Enoch. In 2 Enoch, the two conditions of Adam's corporeality - one before the fall and the other after-are also conveyed through the terminology of greatness and smallness.

In the longer recension of 2 Enoch 30:10, the Lord reveals to the seventh antediluvian hero the mystery of the two conditions or "natures" of Adam, one original and the other fallen. It is striking that these conditions are rendered in the text through the familiar formulae of "greatness and smallness":

From invisible and visible substances I created man.

From both his natures come both death and life.

And [as my image] he knows the word like [no] other creature.

But even at his greatest he is small,

and again at his smallest he is great. ${ }^{34}$

${ }^{32}$ Launderville, "Ezekiel's Cherub," 173-74.

${ }^{33}$ Rubinkiewicz, L'Apocalypse d'Abraham, 116 [translation mine, from Slavonic text].

${ }^{34}$ Francis Andersen, "2 (Slavonic Apocalypse of) Enoch," Old Testament Pseudepigrapha (ed. James H. Charlesworth; 2 vols.; New York: Doubleday, 1983-1985) 1:152. 
Both recensions of the Slavonic text further invoke this terminology in 2 Enoch 44:1: "the Lord with his own two hands created mankind; in a facsimile of his own face, both small and great (мала и велика), ${ }^{35}$ the Lord created [them]." ${ }^{36}$

It is intriguing that both the Apocalypse of Abraham and 2 Enoch use in their description of Bar-Eshath and Adam identical Slavonic terminology which unambiguously points to the Adamic "flavor" of the story of the wooden idol. The description of the fall of Bar-Eshath as a transition "from greatness to smallness" in Apoc. Ab. 6:14 further reinforces this connection with Adamic developments, given that it recalls the tradition about the diminution of Adam's stature after his transgression in Eden in 2 Enoch. ${ }^{37}$

Apocalypse of Abraham 6:15 depicts Bar-Eshath as the one whose "face" (Slav. лицо) has faded: "He fell from the heights to the ground, and he went from greatness to insignificance, and the appearance of his face (взор лица его) ${ }^{38}$ has faded." 39 The notion of Bar-Eshath's fading face is striking in that it again evokes conceptual developments found in 2 Enoch, which uses imagery of divine and human "faces" pervasively and views face not simply as a part of the human or divine body but as a reference to the corporeality of the entire being. The "fading of the face" in this context seems related to the adverse fate of the original body of the first human(s), which literally "faded" when their luminosity was lost as a result of the transgression in Eden. These terminological affinities demonstrate that the authors of the Apocalypse of Abraham were cognizant of the divine Face terminology and its prominent role in the divine body traditions.

\section{Conclusion}

In conclusion of this study it should be noted that investigation into Bar-Eshath's story can help clarify not only the broader ideological context of the anti-corporeal polemical currents found in the Slavonic apocalypse but also the textual issues pertaining to the provisional status of the passage containing the arboreal tale. Since this passage is absent from one of the important manuscripts of the Apocalypse of Abraham, the so-called the Silvester Codex, it has often been considered a later

${ }^{35}$ Matvej I. Sokolov, "Materialy i zametki po starinnoj slavjanskoj literature. Vypusk tretij. VII. Slavjanskaja Kniga Enoha Pravednogo. Teksty, latinskij perevod i izsledovanie. Posmertnyj trud avtora prigotovil k izdaniju M. Speranskij," Chtenija v Obshchestve Istorii i Drevnostej Rossijskih 4 (1910) 1.44, 96. [Matvej I. Sokolov, "Materials and Notes about Ancient Slavonic Literature. 3.VII. Slavonic Book of Enoch the Righteous. Texts, Latin Translation and Study. A Posthumous Edition Prepared by M. Speranskij," Proceedings of the Society of Russian History and Antiquities 4 (1910) 1.44, 96.]

${ }^{36}$ Andersen, "2 Enoch," 1.170.

${ }^{37}$ See 2 Enoch 30:10.

${ }^{38}$ Kulik traces this Slavonic expression to the Hebrew expression דמות פניו (Retroverting the Slavonic Pseudepigrapha, 14 n. 30; 72-73).

${ }^{39}$ Rubinkiewicz, L'Apocalypse d'Abraham, 116; Philonenko-Sayar and Philonenko, L'Apocalypse d'Abraham, 48. 
interpolation..$^{40}$ In this context the establishment of the relationship between the passage and the broader theological framework of the Slavonic apocalypse is important. Our study demonstrates that the passage is consistent with the original theological argument of the work. This research therefore offers additional evidence that the story of the demoted tree is not an interpolation but may rather belong to the original core of the text, as it shares its anti-anthropomorphic polemics and is consonant with its overall ideological agenda.

${ }^{40}$ For example, Box and Landsman consider it "a later interpolation" (Apocalypse of Abraham, 41 n. 5). B. Philonenko-Sayar and M. Philonenko include the passage with the arboreal tale only in the footnotes of their critical edition of the text (L'Apocalypse d'Abraham, 48). 